\title{
Pareto Optimality and the Rule of Law
}

Noel B. Reynolds

Brigham Young University - Provo, nbr@byu.edu

Follow this and additional works at: https://scholarsarchive.byu.edu/facpub

Part of the Political Science Commons

\section{Original Publication Citation}

"Pareto Optimality and the Rule of Law," in Method and Morals in Constitutional Economics :

Essays in Honor of James M. Buchanan, (Studies in Economic Ethics and Philosophy), edited by G. Brennan, H. Kliemt, and R. D. Tollison, Berlin, Springer, 2002, pp.237-252.

\section{BYU ScholarsArchive Citation}

Reynolds, Noel B., "Pareto Optimality and the Rule of Law" (1998). Faculty Publications. 1486.

https://scholarsarchive.byu.edu/facpub/1486 
Publication information:

"Pareto Optimality and the Rule of Law," in Method and Morals in Constitutional Economics : Essays in Honor of James M. Buchanan, (Studies in Economic Ethics and Philosophy), edited by G. Brennan, H. Kliemt, and R. D. Tollison, Berlin, Springer, 2002, pp.237-252.

PARETO OPTIMALITY AND THE RULE OF LAW

August 31, 1998

Noel B. Reynolds

Professor of Political Science

Brigham Young University

Provo, Utah 


\section{PARETO OPTIMALITY AND THE RULE OF LAW}

In 1959, James M. Buchanan criticized the collectivist misuse of Pareto optimality by the "new welfare economists" and made a first attempt to extend that individualist concept into the political realm. ${ }^{1}$ Over the following three decades he further developed his political application of Pareto's insight to buttress an essentially economic analysis of political exchange that would justify the processes of constitutional democracy in the same way Pareto efficiency justifies free markets. In this paper I will explain why Buchanan's particular formulations will not work and propose a more comprehensive solution that accomplishes Buchanan's announced purpose. I will argue that a conventionalist understanding of the rule of law provides a precise and appropriate application of the Pareto criterion in the legal and political realm.

The Pareto criterion has been recognized for some time as a regulative norm by which the efficiency of an economy can be measured in terms of the extent to which the preferences held by individuals were satisfied. The point at which no further voluntary exchanges would take place marks a theoretical point at which everyone is as well off as possible, measured in terms of their own preferences. This differs from utilitarian and other approaches by taking the preferences of individual choosers as facts to be accommodated, not ignored or corrected.

The rule of law has been understood and defined in many ways, including as a regulative norm by some twentieth century legal, economic, and political theorists. Both F. A. Hayek ${ }^{2}$ and Lon L. Fuller ${ }^{3}$ have seen in this traditional legal concept an implicit guideline or measure of freedom as contrasted with tyranny. Michael Oakeshott further clarifies that observing rule of 
law in a polity is a means of ensuring that people are able to use their lives for their own purposes. $^{4}$

\section{Pareto and Wicksell in Buchanan's Political Economy.}

Like other European sociologists and founders of welfare economics at the turn of the century, Pareto believed that social values should play a role in public policy analysis. But he also saw the need to transcend the necessity of interpersonal comparisons in utilitarian analyses. Pareto accomplished this by shifting the analysis away from any kind of social calculation and focusing on the choices people actually make.

We are, hence, led to define a position of maximum ophelimity ${ }^{5}$ as one where it is impossible to make a small change of any sort such that the ophelimities of all individuals with the exception of those that remain constant, are either all increased or all diminished. ${ }^{6}$

Public choice theorists, following Buchanan, emphasize an individualist interpretation of Pareto by assuming the given distribution and focusing on whether individual actors would choose voluntarily to make further exchanges. If not, the system is at an optimum, according to the values of its individual members--the only values which matter.

When Buchanan talks about Pareto optimality from this perspective, he clarifies that he is using the term in a "Wicksellian" contractarian framework. ${ }^{7}$ By this he means that the exchange nexus is the most viable test for the unanimous consent of all interested parties and the best indicator of whether their welfare can be improved by any proposed trade or change, a notion he attributes to the nineteenth century economist Knut Wicksell. The difficulty faced by political economists who want to achieve Pareto efficiency in the social policy realm is that the unanimity 
that characterizes market exchanges is not readily imaginable as a feature of any process of social policy formation. But, if you follow the individualist assumptions of most economics and liberal political theory (social values do not exist apart from individual values) and assume that voluntary trade is proof of mutual gains, then "consensus or unanimity (mutuality of gain) is the only test which can insure that a change is beneficial."

While the basic models of Pareto and Wicksell were indeed compatible and mutually supporting in most important respects, these two great turn-of-the-century social scientists were implacably opposed to one another. ${ }^{9}$ It was Buchanan's genius that saw the essential similarity of their important insights and brought them together in his own work. ${ }^{10}$ More recently, as his interpretation of Pareto has been challenged, Buchanan has tended to emphasize his dependence on Wicksell for the unanimity notion, speaking of the Pareto test "interpreted in Wicksellian terms." 11

Buchanan looks back to Knut Wicksell, not only for the insight that unanimity is the correct ideal for social decision-making, but also for the recognition that some procedure for achieving approximate unanimity is necessary in the real world. While there may be a course all reasonable men would agree to, not all men will be reasonable all the time. This forces Wicksell (and Buchanan) into vague compromise positions, but does not drive them to anything like simple majority rule, which Buchanan and his co-authors have criticized so effectively: ${ }^{12}$ "Here the absolute unanimity rule must be broken; the political economist must try, as best he can, to judge the extent of unanimity required to verify (not refute) his hypothesis. Some less definitive rule of relative unanimity must be substituted for full agreement, as Wicksell recognized and suggested."13 
In 1959 this logic drove Buchanan to endorse the principle of compensation to ensure consensus. Wicksell had previously advanced the idea that tax levies and national budgets should require parliamentary super-majorities of 75) 90 percent. ${ }^{14}$ Buchanan's later work with Gordon Tullock and others demonstrates his full awareness and concern for the problems of lessthan-unanimous decision making. But to this day, he (like Wicksell) sees the political problem of achieving Pareto efficiency as a direct parallel of market efficiency, and focuses on models of political exchange as the means by which some form of unanimity or near-unanimity can be achieved. Comparing Wicksell's "contractarian framework" to the "quasi-utilitarian framework of orthodox welfare economics," Buchanan understands the Wicksellian approach and its emphasis on unanimity as "a straightforward extension of the exchange nexus."15 As I explain below and elsewhere, a less direct analogy in the political and legal realms may provide a more natural and less strained solution. ${ }^{16}$

\section{Using the Pareto Criterion in Welfare Economics.}

In his 1959 entrée to these matters, Buchanan showed that whereas welfare economists "have generally assumed omniscience in the observer," this necessarily means that the observer must rely on "his own estimate of his subjects' value scales," rather than their actual values in making policy recommendations. ${ }^{17}$ This is unavoidable because the subjects' values are only revealed in actual choices and cannot be known in advance by anyone. Because ethical evaluations are necessarily introduced by the observer in this process, each variation of this approach "constitutes a distortion of the Pareto rule." ${ }^{18}$ To maintain social efficiency in the true Paretian spirit, we must look not at the good or bad health (measured by some external value) of the political system, but rather to the level of "agreement" in the system. 
"The political behavior of individuals, not market performance or results, provides the criteria for testing hypotheses of political economy." ${ }^{19}$

This analysis led Buchanan to conclude that a true application of Pareto's efficiency criterion to social policy changes would require compensation to losers. No one can be made worse off, and agreement is the only acceptable measure of welfare so understood. "'Welfare' is defined as that which is expressed by individual preference as revealed in behavior. ${ }^{120}$ Buchanan saw his insistence on the compensation device as another way of defending "the classical liberal conception of democracy itself." ${ }^{21}$

\section{Unanimity in Political Economy.}

Three years after his first article on the topic, James Buchanan took up Pareto optimality and its political implications once again in the context of a critique of the way welfare economists were misusing the idea. ${ }^{22} \mathrm{He}$ again objected to the inevitable intrusion of "social value judgments" or "social welfare functions" by those who wanted to use the Pareto criterion to classify results (1962: 341). ${ }^{23}$ Going beyond his 1959 discussion of a compensation principle, he argued that "the criterion must be extended to classify social rules which constrain the private individual behavior."24

Buchanan developed this point by distinguishing between the choices of particular economic outcomes (results) in a society and the choices of frameworks of rules within which people make the decisions that produce those outcomes. While welfare economists tend to use the Pareto criterion to evaluate and predict outcomes, their proposals are always in terms of policy or changes in the governing body of rules. So the true relevance of the Pareto criterion for welfare economics is in the analysis of alternative sets of rules, not results. To demonstrate this 
point, Buchanan provides us with straightforward examples in which standard evaluation of results indicates sub-optimal situations by Pareto standards while the rules generating the situations may themselves be optimal in that there may be no way of "securing [voluntary] consensus on any change. Thus, the mere demonstration of some violation of Pareto optimality in the orthodox classification of results may not be sufficient to suggest that some change in policy is dictated." ${ }^{25}$

While it might seem that Buchanan's constant movement back and forth between discussions of changes "in policy," "in the constitutional structure," or "in the 'social constitution'" erases any significant differences between these, the conflation actually helps reveal the basic logic of his position. All choice and action take place within a situation structured and bounded by different kinds of rules. The particular hierarchy of rules does not matter so much for this analysis. The entire package of policies, rules, and constitutional provisions defines the region of private action, the results of which can be assessed by welfare economists for Pareto optimality. But the more important question that Buchanan has identified is whether the rules defining those regions are themselves optimal. And the test he proposes, following the pure logic of Pareto optimality, is unanimity: "If a presumed or apparent nonoptimal rule cannot be changed through agreement among members of the group, the hypothesis stating that the rule is nonoptimal is effectively refuted." ${ }^{26}$

And,

"All possible changes in the constitutional structure become admissible so long as these rules changes may, conceptually, be approved by general agreement. The 
unanimity principle for changes in the 'social constitution' provides the only appropriate facultative constraint." ${ }^{27}$

Though I fully endorse Buchanan's shifting to a focus on the rules which define the situation in which economic choices are made, it seems to me that his attempt to apply the Pareto criterion to the choosing of rules cannot work. It is a move that arises from Buchanan's assumption that the process of constitutional choice is best understood as a process of exchange) ) like a market. But it overlooks the fundamental difference in that the unanimity he admires in market choosing never requires everyone in the society to agree with everyone else consciously and explicitly. It is a de facto unanimity which results when the myriad of economic exchanges between individuals are all voluntary. But this is a special kind of agreement, and certainly does not imply that everyone agreed before the fact that the actual state of affairs was to be desired or chosen by the group. That kind of agreement would never be possible in markets either. But social choices about rules are of this kind. When we choose rules, we choose to redefine the situation of all future activity for everyone. It would seem that we have a problem of apples and oranges, and the assumption that constitutional choice is reducible to an exchange process must be defended against our intuitive doubts. While no one will deny the existence of a process of political exchange, it is always aimed at achieving the required majorities, and not unanimity.

Of course, Buchanan does recognize the virtual impossibility of achieving actual unanimity in such matters and here introduces the concept of "the costs of reaching agreement." Rather than undergo such costs, "members of the group may decide, in the constitutional process, to accept the departures from Pareto-optimality that less-than-unanimity voting rules may 
produce." ${ }^{28}$ But we may ask, will they decide this unanimously? The problem persists, possibly in an infinite regress. Any decision process that requires agreement across a society will run aground on the free rider problem. And any compromise with the unanimity requirement fails to preserve the justifying logic of the Pareto criterion.

It seems to me that Buchanan's instincts are exactly right in searching for the most important form of Pareto optimality in the rules of the legal society which define the space within which private action takes place. And he also has to be right in his insistence that as in market activity, unanimity in decision making is the appropriate index of optimality. What does not seem to work as well is the direct assumed parallel between the making of choices by market actors in their limited and self-chosen exchange situations, and social decision making which by its very nature involves every citizen and can hardly ever achieve unanimity.

It is precisely at this point that the conventionalist theory of law described below provides a standard which meets the requirements of Pareto optimality without compromising on social decision-making rules. The rule of law properly describes polities which implicitly regulate all rules changes and policy changes in such a way that constructive unanimity is preserved. Changes which satisfy the principles of rule of law can be seen as fully conventional, based only in agreement and not in coercion. And this amounts to a political-legal equivalent of the Pareto test in economics.

Wicksell was Buchanan's forerunner and inspiration in the effort to preserve the voluntary character of human society by bringing the standard of unanimity or "approximate unanimity" into the realm of constitutional choice. "Wicksell's theoretical interest was to articulate general constitutional principles to which a government must adhere if it is meaningfully to reflect the 
consent of the governed."29 For this his work has been recognized by public choice theorist Richard Wagner as "the first effort at constitutional construction."30

\section{The Rule of Law in Political and Legal Theory.}

It is common in the century of legal positivism to think of law first as a means of social control. The implication is that some people are controlling others and maintaining order through the manipulation and enforcement of legal rules. On this view, the purposes of the rules are the purposes of those who have the power to manipulate others. The effectiveness or appropriateness of a legal system or of any particular legal rule will obviously be measured in terms of its contribution to this purpose. Positivists will tend to understand the rule of law as obedience to law or supremacy of law, without attendant notions of implicit limits on law itself. On this approach, rule of law comes off looking rather weak and useless, except for propaganda purposes, as it finally protects no one from anything.

A persistent counter tradition understands law as a function of social agreements designed to protect and facilitate the freedom of each citizen in the pursuit of his or her self-chosen ends. The law's purpose is to provide a neutral framework for social interaction and individual action that will facilitate cooperative behavior while protecting all from the arbitrary interference or control of others. Thinkers in this tradition have identified the rule of law with individual liberty and the devices or principles that protect individuals from governmental control or manipulation.

Positivist critics have taken this to be a poorly disguised assertion of an ideological view of law, whether it be libertarian or just liberal in a more classical sense. Admittedly, the defenders of this more substantial and limiting notion of rule of law frequently retreat to the selfevident value of individual liberty as a justification for their proposals. This does not satisfy 
critics who would like to see equality and other values given the same consideration. Nor does it satisfy those who believe a theory of law should not be tied to any particular ideological position.

The inadequacy of either view, taken by itself, is generally recognized by contemporary legal theorists. Positivist theory has proven incapable of explaining our most persistent intuition about law, our sense of obligation to obey a rule just because it is valid law. But natural law theory has proven incapable of explaining law as a social fact, often independent of any moral principles. And our modern understanding of the origins and process of law tends to reduce much valid law to nothing more edifying than facts about who wanted and got what when.

\section{Law as Convention.}

The conventionalist theory of law preserves the basic insights of both these approaches. It advances a notion of rule of law derived from social fact rather than ideology, as required by positivists, while providing normative structure and limitation as required by value based approaches. ${ }^{31}$ The beginning claim of this approach is that social situations in which parties are coerced to conform to a norm are categorially distinct from those in which individuals voluntarily coordinate their actions in mutual expectation of benefit. Though it is clear that lovers of liberty will champion the latter situation and despise the former, the claim that the two are factually distinguishable requires no moral evaluation. My theory of law derives from an articulation of the implicit structure of the voluntary alternative when it is expanded to include a whole society. I claim that law understood as an extension of human agreement is vastly different than law understood as a function of habit and coercion, and that the rule of law is the inherent and distinguishing characteristic of law understood as convention. Rule of law becomes the standard 
of voluntariness or conventionality by which rules and legal systems as a whole can be measured. Variations from this standard tend to the coercive model.

The basic criterion of voluntariness or conventionality is unanimity. This is a strong criterion, and becomes more complicated as the size of the group involved increases. The assumption is that what people will agree to unanimously is uncoerced. Presumably, people agree to a coordinated course of conduct with an expectation of realizing some benefit not otherwise attainable and with assurance that any risks involved are limited and worth taking. James M. Buchanan has helped us in his reflections on constitutional political economy to understand unanimity as the basic test for voluntariness. ${ }^{32}$ Note that it is not necessary that parties to an agreement expect benefits to be equally distributed. Nor is it necessary that they see the object of their agreement as the ideal arrangement. They only need see it as their best option, all things considered.

The major claim of this theory is that law rests on a fundamental convention or agreement which creates the legal community and the authority to make rules binding on all community members. Contrary to some economic approaches, including Buchanan's, it does not claim that the foundations of political society can be adequately explained on an exchange or market model. The community of law substitutes authority for unanimous agreement as the grounding of the rules it produces. The power to make and enforce authoritative rules is assigned to public officials whose formal positions are in turn defined by law and are not occupied by personal right. Acting in these authoritative roles, public officials represent the entire community. To use their public offices for personal advantage would subvert both the offices and the law. Their official actions serve as substitutes for the unanimous agreement of the community as a whole. 
Seen in this way, constitutional requirements for different kinds of majorities do not aim at approximating unanimity. Rather, they are prudential devices designed to reduce the likelihood that the power granted to public authorities will become corrupted and misused) ) ) advancing the private interests of the public officials and using the lives the citizens for private advantage.

\section{Constructive Unanimity and the Conditions of Conventionality.}

The move from actual unanimity in social decision making to the establishment of legal authority merely recognizes the practical impossibility of achieving complete agreement on a day by day basis, as well as the temptation to hold out for inordinate concessions that the rule of unanimity creates for individuals. Conventionalism claims that it is rational, given the impossibility of achieving actual agreement on every rule that will necessarily affect all members of the society, to concede one's veto over such rules and agree to institutions of authority on certain conditions that will govern the future exercise of that authority. The creation of legal authority is by definition unanimous as such authority only exists for those who agree to it and choose to take advantage of its existence in their lives. Scholars who have studied the process of social agreement have noted a number of general characteristics of such agreements. I have elsewhere shown how these empirically identified characteristics of actual agreements can be generalized as a set of abstract conditions of agreement.

One of those conditions is that the authority be constrained by a standard of constructive unanimity, that is, that it be limited in its actions to creating and enforcing rules and procedures that all members of the society might reasonably have agreed to in advance. This is not a Rawlsian veil of ignorance. The assumption has to be that people knowing their actual preferences, values, needs, and abilities could reasonably have agreed to let standards be laid 
down by public officials. This notion of constructive or ad hoc unanimity suggests the following as implicit limits on all legal authority:

1. Rules cannot violate the deeply held moral and religious beliefs of citizens. To the extent that these are matters many people hold to be more important than anything else, it is not reasonable to expect them to put these at risk in agreements made with others to improve their situations in other respects. (This may limit the range of moral and religious views that can share a single legal system. But note that it is a negative restraint only and does not require complete moral and religious agreement. It does require religious liberty.)

2. Authoritative decisions cannot arbitrarily single out individuals or groups for particular penalties or benefits.

3. The authorities themselves, in their private role as citizens and in their public roles as magistrates, are subject to all the rules they create.

4. There can only be one set of rules for everyone. There can be no special (privileged) categories of citizens.

5. Rules cannot be changed after the fact or made retroactive in their application without the actual consent of all concerned or compensation to those negatively affected.

6. All making and enforcement of rules must be knowable and observable by all citizens.

7. Every citizen must have reasonable access to the process by which the rules are formulated and administered.

8. Every citizen must have full opportunity to defend his case when accused of rule violations. 
Other conditions of such social conventions could be listed. This short list includes some of the most important conditions of conventionality. The claim is that any social convention to be ruled by law implicitly holds these as limitations on the authorities it creates. These are not moral principles, but are conditions that protect constructive unanimity. It is reasonable to give up one's veto to an authority that can be expected to act within these limitations.

\section{The Principles of the Rule of Law.}

The link between this kind of rational actor analysis and traditional natural law and rule of law theories is that most of these conditions of conventionality can be expressed in terms of the widely recognized principles of rule of law, particularly as these have been articulated by Hayek and Fuller. Elements 1 and 7 on this list have not ordinarily been recognized in rule of law discussions. The others are directly translatable into recognized rule of law principles as follows:

2. The principle of generality--all rules must be general in scope.

3. The principle of generality--the rules must apply to everyone.

4. The principle of equality--there cannot be more than one class of legal persons.

5. The principle of prospectivity--new rules can only apply to the future.

6. The principle of publicity--no secret rules or prosecutions are allowed.

8. The principle of due process--all prosecutions must follow established rules which give defendants and plaintiffs full opportunity to defend their actions and their interests.

On this analysis, the conditions of conventionality or constructive unanimity are equivalent to the principles of the rule of law. Rule of law is revealed as an implicit norm or standard for legal communities that understand law as agreement or convention rather than 
coercion or habit. Rule of law just means constructive unanimity or conventionality. This includes, but goes far beyond the view that authority requires obedience to law. It also entails a broad set of implicit limits on all authority. Not just anything can be a law. There are implicit standards and limits in much the sense that natural lawyers have always wanted. But these standards are not derived from moral principles which may or may not be supported with consensus. Rather, they are derived from social facts, from individual choices made for whatever reasons people (who may be presumed to act according to their own moral convictions and interests) may have as they pursue what they consider to be important in their lives. Thus the theory claims to transcend the recognized impasse in legal theory by basing law in social fact, while identifying broad standards inherent in law.

\section{Rule of Law and Pareto Optimality.}

On the analysis developed here, rule of law, like Pareto optimality, is a regulative norm. In fact, rule of law may just be an extension of Pareto optimality into the legal sphere. This possibility is glimpsed by returning to the two person exchange or agreement on a rule of mutual conduct. At this level, a fully voluntary exchange is by definition Pareto optimal. But how do we extend this measure of voluntariness into a sphere where the choices are being made by some for all, especially given that most of the choices that are made in this way would have been opposed by at least some of the people who are bound to them? The notion of constructive unanimity carries us ahead to this level, which is necessary if these concepts are to be introduced into a theory of law. Using this extended notion of rule of law we can now assess choices made by authorities for the society in terms of "constructive unanimity." We can call a legal system 
conventional or voluntarist in a meaningful way that distinguishes it from other types of social organization that are not based in voluntary choice.

Pareto optimality works well for analyzing a market because individuals are making their own choices on a case by case basis. There are simply an infinite number of ad hoc adjustments that individuals can work out between themselves, which reflect nothing but unanimous choices, but which never require everyone to agree to any one thing. Private property and market exchange make it possible for individuals to act unilaterally without any need for securing the consensus of the society as a whole. But the law is a very different matter. For every rule must by definition be general, and this makes it the business of every citizen. Legal society is also more complex in that individuals delegate some of the most important choices in ways that virtually guarantee that some of the outcomes will not be what they would in fact have chosen. The notion of rule of law as developed here gives us a way of speaking of such situations as if individuals had voluntarily agreed to specific rules. This is important because we still want to distinguish between a political and legal system that is based in voluntariness and one that rests on coercion.

The relatedness of the two criteria is also emphasized by the interesting fact that while they are both social measurements or criteria, dealing with societies as a whole, neither one is holistic. Rather each measure focuses on individuals and measures aggregatively in a way that lets every individual count.

Attempts to use the Pareto criterion in legal analysis have tended toward contractual models. Again, the problem may be the complexity involved in maintaining the sense of the Pareto criterion when you move from the market situation of actual agreement between 
individuals and a legal society in which commitments are made by authorities. Another attempt to get around the limitations of the Pareto criterion in this context is the Kaldor-Hicks test which Posner and others have used to rationalize changes by making cost-benefit calculations and paying off long run losers. This procedure is intended to yield a kind of "constructive consent."

The emphasis in these models is on actual costs and benefits, which can only be calculated ex post facto. The rule of law model spelled out above provides a set of criteria that can be used at any point in time, and therefore are available prospectively.

Oddly enough, even though Pareto optimality turns out to be less abstract or more basic than rule of law, it is dependent on rule of law in the real world. There is little question that a legal system exhibiting rule of law greatly enhances the voluntary choices necessary for Pareto optimality to be realized. The market economy needs law as a precondition.

While the Pareto criterion is not usually thought of in terms of a set of general principles or conditions that people can look to in improving their societies, there are plenty of economists who believe there are general market principles which can profitably be observed by societies that wish to raise their levels of Pareto efficiency. To the extent they are correct, the Pareto criterion indirectly provides the kind of general guidance to free societies that rule of law offers. But neither imposes a universal or maximizing rule. Rather, each protects individuals as the only sources of value. It is from this perspective that it might be said that rule of law and Pareto optimality are the same thing. Each is a measure of the extent to which individuals in a society are able to use their lives for their own purposes, to pursue their self-chosen ends. The main difference is that the Pareto criterion focuses on distribution issues while rule of law focuses on the creation and administration of rules that govern all forms of individual conduct. 


\section{ENDNOTES}

1. J. M. Buchanan, "Positive Economics, Welfare Economics, and Political Economy," Journal of Law and Economics, 2 (1959), pp. 124) 127.

2. F. A. Hayek, The Constitution of Liberty (Chicago, 1960), pp. 205) 206.

3. L. L. Fuller, The Morality of Law (New Haven, rev. ed. 1969), pp. 33) 94.

4. See his major work) ) M. Oakeshott, On Human Conduct (Oxford, 1975)) ) for a full account of this theory and his later and more accessible restatement in M. Oakeshott, "The Rule of Law," in On History and Other Essays (Oxford, 1983), ch. 2.

5. Ophelimity is Pareto's narrowed version of individual utility and is limited to satisfactions that have economic causes. Thus, the Pareto criterion was conceived as a measure of optimal ophelimity, the point at which people would be unwilling to make further moves to increase economic satisfactions.

6. For the complete text in English, see V. Pareto, Manual of Political Economy, A. S. Schwier, trans., A. S. Schwier and A. N. Page, eds. (New York, 1971), Appendix, section 89. However, I have used here the translation of this passage published in R. Cirillo, The Economics of Vilfredo Pareto (London, 1979), p. 43.

7. J. M. Buchanan, Liberty, Market and State: Political Economy in the 1980s (New York, 1985), pp. 264, 270.

8. Buchanan, "Positive Economics," p. 137.

9. P. Hennipman, "Wicksell and Pareto: Their Relationship in the Theory of Public Finance," History of Political Economy, 14 (1982), pp. 37) 64.

10. See R. E. Wagner, "The Calculus of Consent: A Wicksellian Perspective," Public Choice, 56 (1988), pp. 153) 166. 
11. Buchanan, Liberty, Market, and State, pp. 164) 165, 270.

12. See J. M. Buchanan and G. Tullock, The Calculus of Consent: Logical Foundations of Constitutional Democracy (Ann Arbor, 1962).

13. Buchanan, "Positive Economics," p. 135.

14. Knut Wicksell, Finanztheoretische Untersuchungen nebst Darstellung und Kritik des Steuerwesens Schwedens (Jena, 1896). See the long excerpt from the second essay, translated by J. M. Buchanan and published as "A New Principle of Just Taxation," in Classics in the Theory of Public Finance, R. A. Musgrave and A. T. Peacock, eds. (London and New York, 1958). Also see commentary in Hennipman, "Wicksell and Pareto," p. 44 and Wagner, "The Calculus of Consent: A Wicksellian Perspective," pp. 161) 162.

15. Buchanan, Liberty, Market, and State, p. 270.

16. See N. B. Reynolds, "The Ethical Foundations of Constitutional Order: A Conventionalist Perspective," Constitutional Political Economy, 4 (1993), pp. 79) 95.

17. Buchanan, "Positive Economics," p. 126.

18. "Positive Economics," p. 129.

19. "Positive Economics," p. 128.

20. "Positive Economics," p. 130.

21. "Positive Economics," p. 131.

22. See J. M. Buchanan, "The Relevance of Pareto Optimality," The Journal of Conflict Resolution, 6 (1962), pp. 341) 354. Republished in J. M. Buchanan, Freedom in Constitutional Contract: Perspectives of a Political Economist (College Station, 1977), pp. 215) 234. 
23. See "Relevance of Pareto Optimality," p. 341. Buchanan's interpretation of the way the Pareto criterion has been used by welfare economists is reinforced by Renato Cirillo's review of this history, though Cirillo appears more sympathetic to the people Buchanan criticizes. See Cirillo, Economics of Vilfredo Pareto, pp. 42) 60.

24. "Relevance of Pareto Optimality," p. 341.

25. "Relevance of Pareto Optimality," p. 350.

26. "Relevance of Pareto Optimality," p. 353.

27. "Relevance of Pareto Optimality," p. 354.

28. "Relevance of Pareto Optimality," p. 352.

29. See Wagner, "The Calculus of Consent: A Wicksellian Perspective," p. 163.

30. "The Calculus of Consent: A Wicksellian Perspective," p. 162.

31. See N. B. Reynolds, "Law as Convention," Ratio Juris, 2 (March 1989), pp. 105) 120. In "The Ethical Foundations of Constitutional Order" the implications of conventionalism for constitutional theory are also explored.

32. See "Relevance of Pareto Optimality," pp. 345) 347, and Liberty, Market, and State, p. 245. 